http : //ejurnal.pps.ung.ac.id/index.php/AKSARA/index

\title{
Deskripsi Penyesuaian Sosial Siswa Kelas X SMA Negeri 1 Kota Gorontalo
}

\author{
Murhima A. Kau, Misnawati Idris \\ Universitas Negeri Gorontalo \\ murhimakau@ymail.com
}

\begin{abstract}
ABSTRAK
Permasalahan dalam penelitian ini adalah Bagaimana penyesuaian sosial siswa di kelas X SMA Negeri 1 Gorontalo. Tujuan penelitian ini untuk mengetahui penyesuaian sosial siswa di kelas X SMA Negeri 1 Gorontalo. Penelitian ini adalah deskriptif kuantitatif, sampel adalah 48 siswa. Hasil penelitian deskripsi penyesusaian sosial siswa di kelas $\mathrm{X}$ SMA Negeri 1 Gorontalo menggambarkan bahwa memperoleh data hasil persentase dengan berdasarkan indikator 1 Penampilan Nyata menunjukan nilai rata- rata persentase senilai $82 \%$. Berdasarkan indikator 2 Penyesuaian diri terhadap berbagai kelompok menunjukkan nilai rata - rata persentase senilai $75 \%$. Berdasarkan indikator 3 Sikap Sosial menunjukan nilai rata - rata persentase senilai 79\%. Berdasarkan indikator 4 Kepuasan Pribadi menunjukan nilai rata - rata persentase senilai $84 \%$.
\end{abstract}

Kata kunci : Penyesuaian Sosial

\section{PENDAHULUAN}

Manusia secara hakiki merupakan makhluk sosial yang selalu berhubungan dan membutuhkan orang lain dalam kehidupannya. Manusia tidak mampu untuk hidup sendiri tanpa memerlukan bantuan dari orang di sekelilingnya. Seperti yang diungkapkan oleh Gerungan (20011: 26), bahwa sejak manusia dilahirkan ia membutuhkan pergaulan dengan orang lain untuk memenuhi kebutuhan-kebutuhan biologisnya, yaitu makanan, minuman, dan lain-lain. Berdasarkan pendapat Gerungan, sebagai makhluk sosial manusia telah membutuhkan pergaulan dengan orang lain dalam proses kehidupannya. Keseluruhan proses kehidupan individu akan selalu diwarnai hubungan dengan orang lain pada lingkungan tertentu, baik dengan lingkungan keluarga, sekolah, maupun masyarakat luas. Pergaulan dimulai ketika ia lahir hingga melewati berbagai tahapan dalam hidupnya, antara lain masa bayi, masa kanak-kanak awal, masa kanak-kanak akhir, masa remaja, masa dewasa, dan masa tua.

Masa kanak-kanak akhir merupakan masa peralihan dari masa kanak-kanak awal ke masa remaja. Syamsu (2010: 180), mengemukakan bahwa pada masa kanak-kanak akhir ditandai dengan adanya perluasan hubungan, di samping dengan keluarga juga dengan membentuk ikatan baru dengan teman sebaya (peer group) atau teman sekelas yang menyebabkan ruang gerak hubungan sosialnya semakin bertambah luas.

Schneiders (2010:454) mendefinisikan penyesuaian sosial adalah kemampuan untuk bereaksi secara efektif dan sehat terhadap situasi, realitas, dan relasi sosial sehingga tuntutan hidup bermasyarakat dipenuhi dengan cara yang dapat diterima dan memuaskan. Berdasarkan pendapat Schneiders, maka penyesuaian sosial berarti tingkah laku yang mendorong individu untuk menyesuaikan diri dengan orang lain dan kelompok sesuai dengan kesadaran dari dalam diri dan tuntutan lingkungan.

Penyesuaian sosial siswa di sekolah menurut Sofyan Wilis (dalam Nurdin, 2012: 96-97) adalah penyesuaian diri terhadap guru, mata pelajaran, teman sebaya, dan lingkungan sekolah. Penyesuaian diri siswa terhadap guru dipengaruhi oleh sikap guru 


$\begin{array}{ll}\text { Volume } & : 04 \\ \text { Nomor } & : 03 \\ \text { Bulan } & : \text { September } \\ \text { Tahun } & : 2018 \\ \text { http } & : / / \text { ejurnal.pps.ung.ac.id/index.php/AKSARA/index }\end{array}$

dalam menghadapi siswa. Apabila sikap guru lebih bersahabat dan penuh dengan keakraban, maka akan membantu siswa untuk dapat lebih mudah mengenal, memahami, dan menyesuaikan diri dengan karakteristik dan pribadi guru. Penyesuaian diri terhadap mata pelajaran yang seharusnya disesuaikan dengan usia, tingkat kecerdasan, dan kebutuhan-kebutuhan siswa, sehingga siswa dapat dengan mudah menyesuaiakan diri terhadap mata pelajaran.

Penyesuaian diri terhadap teman sebaya dipandang sangat penting bagi perkembangan sosialnya. Menurut Havighurs (dalam Syamsu, 2010: 95) sekolah mempunyai peranan dan tanggung jawab penting dalam membantu siswa mencapai tugas perkembangannya. Jadi sekolah seharusnya berupaya dalam menciptakan iklim yang kondusif atau kondisi yang dapat memfasilitasi siswa untuk mencapai perkembangannya.

Berdasarkan hasil observasi dan program praktek lapangan (PPL) di SMA Negeri 1 Gorontalo terdapat masalah yang sering terjadi dalam penyesuaian sosial ialah masih terdapat siswa tidak percaya akan penampilannya sehingganya sulit bergaul dengan teman-temannya, Pada saat istrahat berlangsung ada siswa yang menyendiri di dalam kelas hal menunjukan bahwa masih ada beberapa siswa yang kesulitan dalam melakukan penyesuaian sosial di sekolah dengan teman sebaya. Penyesuaian sosial siswa di sekolah terdiri atas penyesuaian diri terhadap guru, mata pelajaran, teman sebaya, dan lingkungan sekolah.

Hurlock (2010 : 150) menerangkan bahwa salah satu tugas perkembangan masa remaja yang tersulit adalah yang berhubungan dengan penyesuaian sosial. Remaja harus menyesuaikan diri dengan orang lain diluar lingkungan keluarga untuk mencapai tujuan dari pola sosialisasi dewasa, remaja harus membuat banyak penyesuaian baru.

Perkembangan kehidupan sosial pada masa usia sekolah menengah atas dipengaruhi oleh salah satu aspek penting yaitu penyesuaian sosial. Hal ini didasari karena masa usia sekolah menengah atas adalah fondasi awal terbentuknya sikap dan perilaku pada masa selanjutnya. Didukung oleh pendapat Hurlock (2010:286), menjelaskan pentingnya penyesuaian sosial yang pertama yaitu pola perilaku dan sikap yang dibentuk pada awal masa kehidupan cenderung menetap. Siswa yang mampu melakukan penyesuaian sosial di masa usia sekolah menengah atas, maka akan mempunyai kemungkinan untuk dapat melakukan penyesuaian sosial dengan baik pada masa selanjutnya, dibandingkan dengan siswa yang tidak berhasil melakukan penyesuaian sosial dengan baik. Alasan kedua yaitu jenis penyesuaian sosial yang dilakukan pada masa ini akan meninggalkan ciri pada konsep diri mereka yang akan meningkatkan ketetapan pola penyesuaian sosial yang dilakukan kelak.

WA Gerungan (dalam Nurdin, 2012: 90), mengemukakan faktor-faktor yang mempengaruhi penyesuaian sosial adalah sebagai pertema Peran keluarga yang meliputi status sosial ekonomi, kebutuhan keluarga, sikap, dan kebiasaan orangtua, serta status anak, kedua Peranan sekolah meliputi struktural dan organisasi sekolah, serta peranan guru dalam kegiatan belajar mengajar, ketiga Peranan lingkungan kerja, keempat Peranan media massa, pengaruh alat komunikasi seperti televisi, film, radio, perpustakaan, dan sebagainya.

Begitu pentingnya penyesuaian sosial dalam kehidupan sehari-hari, tak terkecuali dalam dunia pendidikan, maka amatlah penting penyesuaian sosial untuk dikaji dan diperhatikan. 


$\begin{array}{ll}\text { Volume } & : 04 \\ \text { Nomor } & : 03 \\ \text { Bulan } & : \text { September } \\ \text { Tahun } & : 2018 \\ \text { http } & : \text { //ejurnal.pps.ung.ac.id/index.php/AKSARA/index }\end{array}$

\section{KAJIAN TEORETIS}

\section{Hakikat Penyesuaian Sosial}

Pada dasarnya manusia adalah makhluk sosial yang selalu membutuhkan kehadiran orang lain untuk berinteraksi. Agar hubungan interaksi berjalan baik diharapkan manusia mampu untuk beradaptasi atau menyesuaikan diri terhadap lingkungan fisik maupun lingkungan sosialnya. Jadi kemampuan seseorang dalam beradaptasi dengan lingkungannya dipengaruhi oleh kemampuan penyesuaian dirinya.

\section{Pengertian Penyesuaian Sosial}

Penyesuaian sosial merupakan suatu istilah yang banyak merujuk pada proses penyesuaian diri seseorang dalam konteks interaksi dengan lingkungan sekitar. Penyesuaian sosial merupakan suatu proses yang berlangsung seumur hidup dan dilakukan oleh setiap individu agar dapat berperan dan berfungsi di dalam kehidupannya, dimana individu melakukan penyesuaian dalam berhubungan dengan lingkungan dan sesama manusia. Manusia sebagai makhluk sosial tidak dapat berdiri sendiri, mereka membutuhkan orang lain untuk saling bekerjasama dan tolong-menolong untuk memenuhi segala kebutuhannya seperti kebutuhan individu akan pergaulan, penerimaan, dan pengakuan orang lain atas dirinya.

Schneiders (2010:454) mengemukakan "Sosial adjustment signifies the capacity to react affectively and wholesomely to sosial realities, situation and relations do that the requirement for sosial living are fulfilled in an acceptable and satisfactory manner. "

Penyesuaian sosial adalah kemampuan untuk bereaksi secara efektif dan sehat terhadap situasi, realitas dan relasi sosial sehingga tuntutan hidup bermasyarakat dipenuhi dengan cara yang dapat diterima dan memuaskan. Pengertian penyesuaian sosial menurut Kartini Kartono (dalam Nurdin, 2012:87) ialah: "(1) penjalinan secara harmonis suatu relasi dengan lingkungan sosial; (2) mempelajari tingkah laku yang diperlukan, atau mengubah kebiasaan yang ada, sedemikian rupa, sehingga cocok bagi suatu masyarakat sosial".

Berdasarkan pendapat dari para ahli, dapat disimpulkan bahwa penyesuaian sosial adalah tingkah laku yang mendorong individu untuk menyesuaikan diri dengan orang lain dan kelompok sesuai dengan kesadaran dari dalam diri dan tuntutan lingkungan. Keberhasilan individu dalam melakukan penyesuaian sosial antara lain kemampuan individu dalam menjalin komunikasi dengan orang lain, dapat mengembangkan sikap sosial yang menyenangkan, seperti memberi bantuan kepada orang lain, memenuhi aturan, dan mampu mengaktualisasikan dirinya dalam kelompok, serta mampu bertindak sesuai dengan norma yang berlaku, toleransi, dan lain sebagainya.

Penyesuaian sosial siswa disekolah dalam penelitian ini diartikan sebagai kemampuan siswa untuk menyesuaikan diri di dalam berinteraksi dengan orang lain dan situasi-situasi tertentu yang ada di sekitar lingkungan sekolah yang terdiri atas guru, teman sebaya, mata pelajaran, dan hal-hal lain yang berkaitan dengan kondisi sekolah secara efektif dan sehat sehingga siswa memperoleh kepuasan dalam upaya memenuhi kebutuhan yang dapat dirasakan dan berdampak pada dirinya, orang lain, serta lingkungannya.

\section{Ciri-Ciri Penyesuaian Sosial}

Siswa harus mampu menyesuaikan diri dengan segala kondisi dirinya sendiri dan lingkungan sosialnya. Tetapi, tidak semua siswa selalu berhasil dalam proses penyesuaian sosial. Banyak masalah-masalah yang muncul dihadapi siswa seiring dengan proses perkembangannya yang berlangsung sepanjang hayat, Adapun cirri - ciri penyesuaian 


$\begin{array}{ll}\text { Volume } & : 04 \\ \text { Nomor } & : 03 \\ \text { Bulan } & : \text { September } \\ \text { Tahun } & : 2018 \\ \text { http } & : / / \text { jurnal.pps.ung.ac.id/index.php/AKSARA/index }\end{array}$

sosial. Menurut Schneiders (2010: 51) mengemukakan ciri penyesuaian sosial yang baik sebagai berikut:

1. Memiliki pengendalian diri yang tinggi dalam menghadapi situasi atau persoalan, dengan kata lain tidak menunjukan ketegangan emosi yang berlebihan.

2. Tidak menunjukan mekanisme psikologis yang berlebihan, bertindak wajar dalam memberikan reaksi terhadap masalah dan konflik yang dihadapi. mampu mengolah pikiran dan perasaan dengan baik, sehingga menemukan cara-cara yang tepat untuk menyelesaikan masalahnya.

3. Memiliki pertimbangan rasional dan pengendalian diri, memiliki kemampuan dasar berfikir serta dapat memberikan pertimbangan terhadap tingkah laku yang diperbuat untuk mengatasi masalah yag dihadapinya.

4. Mampu belajar sehingga dapat mengembangkan kualitas dirinya terutama dalam bersedia belajar dari pengalaman dan memanfaatkan pengelaman tersebut dengan baik.

5. Mempunyai sikap realistik, objektif, dapat menilai situasi, masalah dan kekurangan dirinya secara objektif.

Ketidakmampuan menyesuaikan diri terhadap lingkungan sosial terlihat dari ketidakpuasan terhadap diri sendiri dan lingkungan sosial serta memiliki sikap-sikap yang menolak realitas dan lingkungan sosial. Siswa yang mengalami perasan ini merasa terasing dari lingkungannya, akibatnya ia tidak mengalami kebahagiaan dalam berinteraksi dengan teman-teman sebaya atau keluarganya.

Ketidakbahagiaan siswa kadang-kadang lebih karena masalah-masalah pribadi daripada masalah-masalah lingkungan, namun memiliki pengaruh yang signifikan terhadap kemampuan sosialnya, dalam hal ini penyesuaian sosial. Memiliki perasaan rendah diri, tidak mau menerima kondisi fisik, tidak memahami kekurangan dan kelebihan diri sendiri, maka ini pun dapat mengakibatkan remaja menolak diri, sehingga proses interaksi sosialnya pun akan terhambat. Jika siswa realistis tentang segala kelebihan dan kekurangan yang mereka miliki, dan merasa bahagia pada orang-orang yang menerima mereka serta mampu mencurahkan perhatian dan kasih sayang pada orang-orang tersebut, kemungkinan untuk merasa bahagia akan meningkat. Artinya bahwa siswa memiliki penyesuaian sosial yang sehat.

Siswa pada penelitian berada pada rentang usia 15-17 tahun, rentang usia tersebut termasuk pada masa remaja madya. Pada masa ini berkembang "social cognition", yaitu kemampuan untuk memahami orang lain (Syamsu, 2010: 198). Siswa memahami orang lain di sekitarnya sebagai individu yang unik, baik yang menyangkut fisik, sifat-sifat pribadi, minat, nilai-nilai, maupun perasaannya. Pemahaman ini mendorong siswa untuk menjalin hubungan sosial yang lebih akrab dengan mereka (terutama teman sebaya), baik melalui jalinan persahabatan maupun percintaan (pacaran) (Syamsu, 2010: 198).

\section{Aspek-Aspek Penyesuaian Sosial}

Hurlock (2010: 287) telah mengemukakan berbagai aspek dalam penyesuaian sosial, diantaranya:

1. Penampilan nyata

Overt performance yang diperlihatkan individu sesuai norma yang berlaku di dalam kelompoknya, dapat memenuhi harapan kelompoknya, berarti individu dapat memenuhi harapan kelompoknya dan ia diterima menjadi anggota kelompok tersebut.

2. Penyesuaian diri terhadap berbagai kelompok 


$\begin{array}{ll}\text { Volume } & : 04 \\ \text { Nomor } & : 03 \\ \text { Bulan } & : \text { September } \\ \text { Tahun } & : 2018 \\ \text { http } & : \text { //ejurnal.pps.ung.ac.id/index.php/AKSARA/index }\end{array}$

Individu mampu menyesuaikan diri atau beradaptasi dengan baik dengan setiap kelompok yang dimasukinya, baik peer/teman sebaya, dan kelompok orang dewasa.

3. Sikap sosial

Individu dapat memperlihatkan dan menunjukkan sikap yang menyenangkan terhadap orang lain, individu mampu berpartisipasi dan dapat menjalankan perannya sebagai individu yang baik dalam berbagai kegiatan sosial, hal tersebut mampu membuat penilaian dari orang lain bahwa individu tersebut dapat menyesuaikan diri dengan baik secara sosial.

4. Kepuasan pribadi

Individu memiliki perasaan puas di dalam dirinya, ditandai dengan adanya rasa puas dan bahagia karena turut ikut ambil bagian dalam aktivitas kelompoknya dan mampu menerima keadaan diri sendiri dengan apa adanya dalam situasi sosial.

Ahli lain berpendapat bahwa Aspek-aspek penyesuaian sosial meliputi :

1. Aspek afektif emosional meliputi: perasaan aman, percaya diri, semangat, perhatian, tidak menghindar, mampu memberi dan menerima cinta, berani.

2. Aspek perkembangan intelektual atau kognitif, meliputi: kemampuan memahami diri dan orang lain, kemampuan berkominikasi dan kemampuan melihat kenyataan hidup.

3. Aspek perkembangan sosial meliputi: mengembangkan potensi, mandiri, fleksibel, partisifatip, dan bekerja sama (Zainun, 2011: 6).

Penelitian ini mengacu pada pendapat Hurlock. Aspek-aspek penyesuaian sosial terdiri atas penampilan nyata (tentang bagaimana individu dapat memenuhi harapan kelompoknya), penyesuaian diri terhadap kelompok (bagaimana individu beradaptasi dengan kelompok), sikap sosial (sikap baik yang ditunjukkan individu ketika mampu beradaptasi dengan kelompok), dan kepuasan pribadi (adanya kesadaran diri).

\section{Faktor-Faktor yang Mempengaruhi Penyesuaian Sosial}

Setiap individu memiliki kemampuan untuk menyesuaikan diri dengan lingkungannya. Kemampuan individu dalam menyesuaikan diri dengan lingkungannya tidak sama antara individu yang satu dengan individu yang lain. Proses penyesuaian ditentukan oleh beberapa faktor yang menentukan kepribadian, baik faktor internal maupun faktor eksternal. Sunarto dan Hartono menjelaskan beberapa faktor-faktor yang mempengaruhi penyesuaian individu, dimana penyesuaian sosial merupakan salah satu aspek dari penyesuaian diri, maka faktor-faktor yang mempengaruhi penyesuaian sosial pun sama dengan faktor-faktor yang mempengaruhi penyesuaian diri, yang diklasifikasikan menjadi tiga bagian, yaitu faktor fisik, faktor psikis, dan faktor lingkungan.

Sunarto dan Hartono (2011: 229-231), menjelaskan faktor internal yang mempengaruhi penyesuaian sosial diantaranya:

1. Faktor Fisik

a. Kondisi jasmaniah

Struktur jasmaniah merupakan kondisi primer bagi tingkah laku karena sistem saraf, kelenjar, dan otot adalah faktor penting dalam proses penyesuaian sosial. Apabila terjadi gangguan-gangguan pada sistem saraf, kelenjar, dan otot dapat menyebabkan gejala gangguan kepribadian, tingkah laku, dan gangguan mental. Kondisi kesehatan jasmaniah yang baik akan mempengaruhi 


$\begin{array}{ll}\text { Volume } & : 04 \\ \text { Nomor } & : 03 \\ \text { Bulan } & : \text { September } \\ \text { Tahun } & : 2018 \\ \text { http } & : / / \text { jurnal.pps.ung.ac.id/index.php/AKSARA/index }\end{array}$

penyesuaian sosial. Jadi jika penyesuaian sosial yang baik dapat diperoleh dan dijaga dalam kondisi kesehatan jasmaniah yang baik.

b. Perkembangan, kematangan, dan penyesuaian diri

Dalam suatu proses perkembangan, respon anak berkembang dari respon yang bersifat instinktif menjadi respon yang diperoleh melalui belajar dan pengalaman yang telah dialaminya. Perubahan dan perkembangan respon individu terus meningkat sesuai dengan kian bertambahnya usia. Individu yang semakin bertambah usianya, menjadi semakin matang untuk melakukan respon yang menentukan pola penyesuaian sosialnya. Pola-pola penyesuaian sosial setiap individu berbeda, tidak sama antara individu yang satu dengan yang lainnya, hal tersebut dipengaruhi oleh tingkat kematangan yang dicapai individu berbeda-beda. Emosi, sosial, moral, dan intelektual merupakan aspek kepribadian seseorang yang dipengaruhi oleh kondisi perkembangannya.

2. Faktor Psikologis

a. Pengalaman

Pengalaman individu turut mempengaruhi penyesuaian sosial. Pengalaman yang mempengaruhi penyesuaian sosial yaitu diantaranya pengalaman yang menyenangkan, cenderung menimbulkan penyesuaian sosial yang baik, serta pengalaman traumatik, yaitu pengalaman yang cenderung mengakibatkan kegagalan dalam suatu penyesuaian sosial.

b. Belajar

Belajar adalah faktor dasar pada penyesuaian sosial. Melalui belajar, akan berkembang pola-pola respon yang akan membentuk suatu kepribadian. Belajar dalam proses penyesuaian sosial adalah modifikasi tingkah laku sejak fase-fase awal yang berlangsung terus menerus berkesinambungan dan diperkuat oleh kematangan individu.

c. Determinasi

Determinasi diri merupakan suatu faktor kekuatan yang mendorong individu untuk dapat mencapai sesuatu yang baik maupun sesuatu yang buruk, yang bertujuan untuk mencapai taraf penyesuaian yang tinggi atau yang dapat merusak diri. Determinasi diri berperan penting dalam proses penyesuaian sosial karena memiliki peranan dalam pengendalian pola dan arah pada penyesuaian sosial.

\section{d. Konflik}

Setiap individu dipastikan memiliki konflik dalam hidupnya. Konflik yang dihadapi tiap individu memiliki berbagai efek yang berpengaruh pada perilaku, namun efek konflik pada perilaku individu tergantung pada sifat konflik, diantaranya yaitu merusak, mengganggu, dan menguntungkan. Setiap individu memiliki cara tersendiri dalam mengatasi konflik, jadi antara individu satu dengan yang lain berbeda dalam menangani konflik. Cara-cara mengatasi konflik tersebut diantaranya dapat meningkatkan usaha ke arah pencapaian tujuan yang menguntungkan secara sosial. Individu yang mudah melakukan penyesuaian sosial yang baik dalam berbagai situasi yang berbeda adalah individu yang dapat mengatasi konflik yang telah dialaminya.

Faktor eksternal yang mempengaruhi penyesuaian sosial menurut Sunarto dan Hartono (2011: 232-234), yaitu faktor lingkungan yang mencakup: 


$\begin{array}{ll}\text { Volume } & : 04 \\ \text { Nomor } & : 03 \\ \text { Bulan } & : \text { September } \\ \text { Tahun } & : 2018 \\ \text { http } & : / / \text { jurnal.pps.ung.ac.id/index.php/AKSARA/index }\end{array}$

1. Pengaruh rumah tangga dan keluarga

Keluarga merupakan satuan kelompok sosial terkecil yang pertama kali menjadi tempat individu dalam melakukan interaksi sosial. Keluarga adalah faktor yang sangat penting dalam mengkondisikan penyesuaian sosial anak, anak belajar bersosialisasi pertama kali dengan keluarganya, anak diberikan dan diajarkan bagaimana menjadi makhluk sosial di dalam keluarga dan selanjutnya dikembangkan di masyarakat.

2. Hubungan orangtua dan anak

Proses penyesuaian sosial anak dipengaruhi oleh beberapa pola hubungan antara orangtua dan anak, diantaranya yaitu:

a. Menerima (acceptance), merupakan situasi dimana orangtua dapat menerima anaknya dengan baik, yang dapat menimbulkan suasana hangat, penuh kasih sayang, dan rasa aman bagi anak.

b. Menghukum dan disiplin yang berlebihan. Disiplin yang diterapkan oleh orangtua sebenarnya memiliki dampak positif yaitu dapat membantu untuk mengkontrol anak, namun jika disiplin itu ditanamkan secara berlebihan atau terlalu kaku, dapat berakibat buruk pada anak yaitu menimbulkan suasana psikologis yang akan merugikan anak.

c. Memanjakan dan melindungi anak secara berlebihan dapat mengakibatkan perasaan tidak aman bagi anak, anak cenderung memiliki sikap rendah diri, serta gejala-gejala buruk yang lainnya.

d. Penolakan, suatu pola dimana orangtua menolak kehadiran anaknya, mengakibatkan hambatan dalam proses penyesuaian sosial anak, anak mengalami kesulitan dalam bersosialisasi.

3. Hubungan saudara

Hubungan antar saudara memiliki pengaruh dalam proses penyesuaian sosial anak. Apabila terjalin suasana hubungan saudara yang kooperatif, penuh persahabatan, penuh kasih sayang, dan saling menghormati dapat memudahkan tercapainya penyesuaian sosial yang lebih baik, begitupun sebaliknya apabila terjadi suasana yang penuh dengan kebencian, perselisihan, permusuhan, dan pertengkaran antara saudara akan menimbulkan kesulitan dan kegagalan dalam mencapai penyesuaian sosial yang baik.

4. Masyarakat

Masyarakat merupakan suatu kelompok sosial yang paling besar dan berpengaruh besar pada pola hidup anggotanya. Keadaan lingkungan masyarakat adalah kondisi yang menentukan proses penyesuaian sosial.

Secara keseluruhan kepribadian mempunyai fungsi sebagai penentu primer terhadap penyesuaian sosial. Penentu berarti faktor yang mendukung, mempengaruhi, atau menimbulkan efek pada proses penyesuaian sosial Menurut Hurlock (2010: 287) faktor-faktor yang mempengaruhi penyesuaian sosial yaitu:

1. Pola perilaku sosial yang dikembangkan di rumah

Pola perilaku sosial yang diterapkan di rumah atau dalam lingkungan keluarga mempengaruhi penyesuaian sosial di lingkungan, baik lingkungan sekolah maupun lingkungan masyarakat. Apabila pola perilaku yang dikembangkan di rumah bersifat buruk, maka anak akan menemui kesulitan untuk melakukan penyesuaian sosial yang baik di lingkungan luar, begitupun sebaliknya apabila 


$\begin{array}{ll}\text { Volume } & : 04 \\ \text { Nomor } & : 03 \\ \text { Bulan } & : \text { September } \\ \text { Tahun } & : 2018 \\ \text { http } & : / / \text { ejurnal.pps.ung.ac.id/index.php/AKSARA/index }\end{array}$

penyesuaian sosial di rumah baik maka anak dalam melakukan penyesuaian sosial tidak akan mengalami hambatan.

2. Model perilaku untuk ditiru

Orangtua seharusnya memberikan contoh dan menjadi tauladan yang baik bagi anaknya. Memberikan perilaku yang baik untuk ditiru di lingkungan rumah akan mempermudah anak dalam melakukan penyesuaian sosial di luar rumah, begitu sebaliknya apabila di lingkungan rumah kurang adanya model perilaku untuk ditiru maka anak akan mengalami hambatan dalam penyesuaian sosial di luar rumah.

3. Belajar

Kurangnya motivasi untuk belajar melakukan penyesuaian sosial sering timbul dari pengalaman sosial awal yang tidak menyenangkan di rumah atau di luar rumah, sedangkan belajar dari pengalaman yang menyenangkan akan memberikan motivasi dalam penyesuaian sosial di dalam rumah atau di luar rumah.

4. Bimbingan dari orangtua

Bimbingan orangtua sangatlah penting untuk melatih anak melakukan penyesuaian sosial dengan baik. Untuk itu sebagai orangtua sebaiknya bersikap aktif dalam membimbing dan mendidik anak.

WA Gerungan (dalam Nurdin, 2012: 90), mengemukakan faktor-faktor yang mempengaruhi penyesuaian sosial adalah sebagai berikut:

1. Peran keluarga yang meliputi status sosial ekonomi, kebutuhan keluarga, sikap, dan kebiasaan orangtua, serta status anak.

2. Peranan sekolah meliputi struktural dan organisasi sekolah, serta peranan guru dalam kegiatan belajar mengajar.

3. Peranan lingkungan kerja.

4. Peranan media massa, pengaruh alat komunikasi seperti televisi, film, radio, perpustakaan, dan sebagainya.

Berdasarkan uraian, dapat disimpulkan bahwa faktor-faktor penyesuaian sosial terdiri dari faktor internal dan faktor eksternal. Faktor internal yang mempengaruhi yaitu berupa faktor fisik dan faktor psikologis. Faktor fisik terdiri atas kondisi jasmani dan perkembangan/kematangan individu, sedangkan faktor psikologis berupa pengalaman yang dialami individu, pembelajaran akan suatu yang telah terjadi, konflik yang dihadapi individu, dan determinan. Faktor eksternal yang mempengaruhi yaitu, keluarga, terdiri dari pengaruh pola asuh keluarga, hubungan yang harmonis dalam keluarga, yaitu hubungan yang melibatkan antara orangtua dan anak, serta dengan saudara, untuk terciptanya suasana yang penuh cinta kasih, kehangatan, keceriaan, serta peran masyarakat, peranan sekolah beserta anggotanya, guru, konselor, dan lain sebagainya, budaya dan agama juga menjadi indikasi penyesuaian sosial yang baik jika semua berjalan selaras.

\section{METODE PENELITIAN}

Desain penelitian ini desain penelitian deskriptif kuantitatif dengan desain satu variabel yaitu penyesuaian sosial siswa. Sampel dalam penelitian ini adalah siswa kelas X SMA Negeri 1 Kota Gorontalo sejumlah 48 siswa. Teknik pengumpulan data dengan menggunakan angket skala likert. Teknik analisis data yang digunakan dalam penelitian 
ini adalah teknik deskriptif dengan menggunakan statistik perhitungan persentase (\%) dengan rumus $(\mathrm{P}=\mathrm{S} / \mathrm{N} \times 100 \%)$.

\begin{tabular}{|l|l|}
\hline Skor Persentase & Klasifikasi \\
\hline $76-100 \%$ & Baik \\
\hline $56-75 \%$ & Cukup \\
\hline $40-55 \%$ & Kurang \\
\hline $0-39 \%$ & Tidak baik \\
\hline
\end{tabular}

\section{HASIL PENELITIAN DAN PEMBAHASAN}

\section{Hasil Penelitian}

Data yang telah diperoleh dari hasil pengolahan angket tentang penyesuaian sosial siswa kelas X di SMA Negeri 1 Kota Gorontalo selanjutnya diolah dengan menggunakan perhitungan persentase. Hasil dari pengolahan data tersebut ditampilkan dalam bentuk grafik berikut ini.

Grafik 1. rekapitulasi penyesusaian sosial siswa di kelas X SMA Negeri 1 Gorontalo.

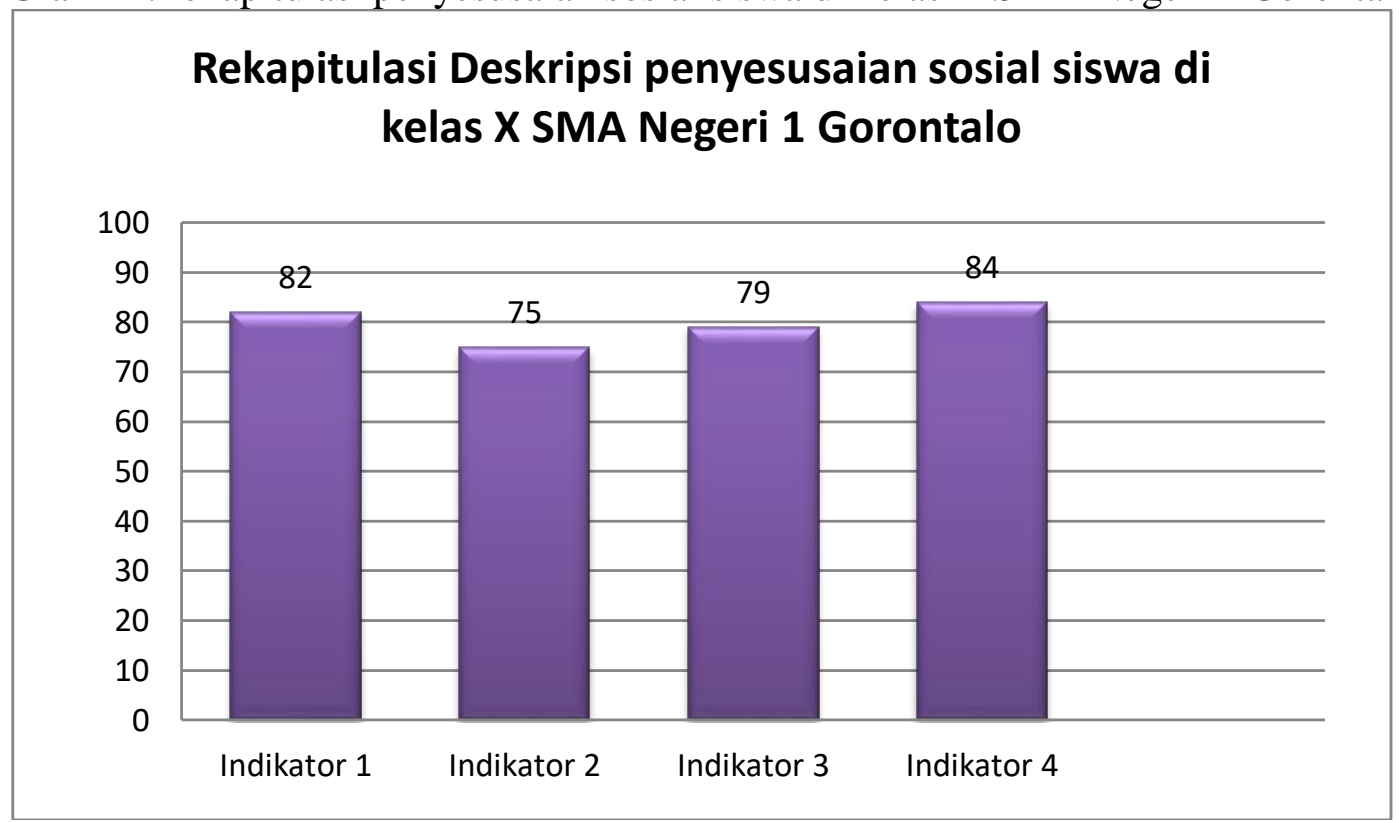

Berdasarkan grafik Deskripsi penyesusaian sosial siswa di kelas X SMA Negeri 1 Gorontalo, yang dianalisis melalui 4 penyesusaian sosial diperoleh persentase dengan jumlah rata-rata $80 \%$ berdasarkan standar penilaian. Hal ini menunjukkan bahwa angka tersebut masih berada pada kategori baik. Pada indikator 1 memperoleh persentase sejumlah $82 \%$ hal ini menunjukkan bahwa siswa mampu memenuhi harapan kelompoknya dan ia diterima menjadi anggota kelompok tersebut. Pada indikator 2 memperoleh persentase sejumlah $75 \%$ hal ini dapat dilihat bahwa siswa mampu menyesuaikan diri atau beradaptasi dengan baik dengan setiap kelompok yang dimasukinya, baik peer/teman sebaya, dan kelompok orang dewasa. Pada indikator 3 memperoleh persentase sejumlah $79 \%$ hal ini menunjukkan bahwa siswa mampu memperlihatkan dan menunjukkan sikap yang menyenangkan terhadap orang lain, individu mampu berpartisipasi dan dapat menjalankan perannya sebagai individu yang baik dalam berbagai kegiatan sosial, hal tersebut mampu membuat penilaian dari orang lain bahwa individu tersebut dapat menyesuaikan diri dengan baik secara sosial.. Pada 


$\begin{array}{ll}\text { Volume } & : 04 \\ \text { Nomor } & : 03 \\ \text { Bulan } & : \text { September } \\ \text { Tahun } & : 2018 \\ \text { http } & : / / \text { jurnal.pps.ung.ac.id/index.php/AKSARA/index }\end{array}$

indikator 4 memperoleh persentase sejumlah $84 \%$ hal ini menunjukkan bahwa siswa mampu memiliki perasaan puas di dalam dirinya, ditandai dengan adanya rasa puas dan bahagia karena turut ikut ambil bagian dalam aktivitas kelompoknya dan mampu menerima keadaan diri sendiri dengan apa adanya dalam situasi sosial.

\section{PENUTUP}

Beradasarkan hasil penelitian dan pembahasan bahwa yang sudah dijabarkan mengenai Deskripsi penyesusaian sosial siswa di kelas X SMA Negeri 1 Gorontalo menggambarkan bahwa memperoleh data hasil persentase sebesar $80 \%$ dengan berdasarkan indikator 1 Penampilan Nyata menunjukan nilai rata- rata persentase senilai $82 \%$. Berdasarkan indikator 2 Penyesuaian diri terhadap berbagai kelompok menunjukkan nilai rata - rata persentase senilai 75\%. Berdasarkan indikator 3 Sikap Sosial menunjukan nilai rata - rata persentase senilai 79\%. Berdasarkan indikator 4 Kepuasan Pribadi menunjukan nilai rata - rata persentase senilai $84 \%$.

Dari hasil penelitian yang sudah dijabarkan maka dapat disimpukan bahwa Penyesusaian Sosial dapat memperoleh persentase yang cukup tinggi. Sehingga Deskripsi penyesusaian sosial siswa di kelas X SMA Negeri 1 Gorontalo dikategorikan cukup baik.

\section{DAFTAR PUSTAKA}

Akinlolu, David. A. (2010). The Buffering Effect of Emotional Intelligence on The Adjusment of Secondary School Transition. Electronic Journal Of Research of Educational Psychology

Hurlock, Elizabeth B.2010. Psikologi Pekembangan Jilid 5. Penerjemah: Meitasari T. \& Muslichah Z. Jakarta: Gramedia Pustaka Utama.

Moh. Nazir. (2011). Metode Penelitian. Bogor: Ghalia Indonesia.

Nana Syaodih Sukmadinata. (2012). Landasan Psikologi Proses Pendidikan. Bandung: PT Remaja Rosdakarya.

Nurdin. (2012). Pengaruh kecerdasan emosional terhadap penyesuaian sosial siswa di sekolah. Jurnal Administrasi Pendidikan, IX

Riduwan. 2013. Belajar Mudah Penelitian untuk Guru, Karyawan dan Peneliti Pemuda. Bandung : Alfabeta.

Saifuddin Azwar. (2013). Penyusunan Skala Psikologi. Yogyakarta: Pustaka Belajar.

Schneiders, Alexander A. (2010). Personal Adjustment and Mental Health. New York: Holt, Reinhart dan Winstons.

Shapiro, Lawrence E. (2013). Mengajarkan Emotional Intelligence Pada Anak. Penerjemah: Alex Tri K. \& Damanik. Jakarta: Gramedia Pustaka Utama.

Sugiyono. (2012). Statistika Untuk Penelitian. Bandung: Alfabeta.

Sukmadinata, Nana Syaodih. (2009). Metode Penelitian Pendidikan. Bandung: Rosda.

Sunarto \& Hartono. (2011). Perkembangan Peserta Didik. Jakarta: Rineka Cipta.

Sutrisno Hadi. (2010). Metodologi Research. Yogyakarta: Andi Offset.

Syamsu Yusuf. (2010). Psikologi Perkembangan Anak dan Remaja. Bandung: Remaja Rosdakarya.

W. A. Gerungan. (2011). Psikologi Sosial. Bandung: PT Refika Aditama.

Zainun. 2011. Psikologi Anak. Jakarta: Gramedia. 